Research Article

\title{
Distribution and Attachment of Bryozoans in the Intertidal Region of South Andaman Island
}

\author{
Mohammed Naufal, Anil Pathan, Kadeparambil Arjunan Jayaraj * \\ Department of Ocean Studies and Marine Biology, School of Life Sciences, Pondicherry University, Andaman \\ Islands 744112, India
}

Article history:

Submission January 2018

Revised March 2018

Accepted May 2018

*Corresponding author:

E-mail: jayarajarjunk@gmail.com

\begin{abstract}
Aiming to collate the distribution and the attachment preference of intertidal bryozoan of Andaman waters, a study was carried out in three intertidal sites (Burmanallah, Kodiyaghat, and Chidiytapu) of southeastern coasts of the Andaman Islands between June and August 2016. The present study is the first exclusive report on bryozoans from the Andaman Islands after a long research gap of nine decades. During our investigation, a total of twelve genera were identified from both calcareous and noncalcareous substratum. Out of the twelve genera, eight genera were new records from the island. The present study showed that the attachment affinity of the Bryozoans is more towards natural substratum particularly on the rocks. The Thalamoporella sp. reported the most abundant species with maximum average colony length of $3.5 \mathrm{~cm}$ from the rock substratum.
\end{abstract}

Keywords: Bryozoa, colony length, intertidal, South Andaman, substratum

\section{Introduction}

Bryozoans (moss animals, sea mats or lace corals) are minute aquatic organisms which are grouped under phylum Ectoprocta. It forms colonies made up of box-like or tubular modules called zooids. These have various forms, but the fundamental unit, a feeding zooid (autozooid), comprises a body wall enclosing a polypide (lopophore and digestive tract) [1]. Bryozoan colonies are mostly encrusting on rocks, shells, seaweeds, and seagrasses. However, they can also be bushy (resembling hydroids or turfing algae) or large and foliaceous like some corals. Intertidal bryozoans are of concern for some reasons [2]. Bryozoans from intertidal zone contain not only inter-tidally restricted species but also those which extend into adjacent subtidal areas. Consequently, by collecting intertidal species, it is possible to take comparable samples of significant richness at numerous localities over broad geographic ranges which are quite useful from the perspective of zoogeography and biodiversity. Being filter feeders, Bryozoans control planktonic population and help in marine ecological balance. Bryozoans are potential in the production of promising novel anti-tumor natural products in the medical research [3]. Fouling behavior of bryozoans on pilings, pipes, and boats are a common threat in the harbors and related industries in maritime countries. This ecological and economic significance of bryozoans led to an extensive study on it throughout the world.

A systematic study of Bryozoan is primarily based on the highly calcified zooecia [1]. Circumscribed bryozoans include three classes, four orders, 187 families, 808 genera and about 6000 species [4]. A total of 257 marine species have been identified from Indian EEZ so far. However, the reports from Andaman and Nicobar, which covers $30 \%$ of Indian EEZ with rich repositories of biodiversity and endemicity, is below $18 \%$, due to its remoteness and lack of research [5]. The available literature on Andaman bryozoans are scanty [6, 7, 8]. Till now no comprehensive attempt has been made to work out taxonomical and ecological aspects of intertidal bryozoans in detail. This paucity of information on bryozoans from the coastal wa- 


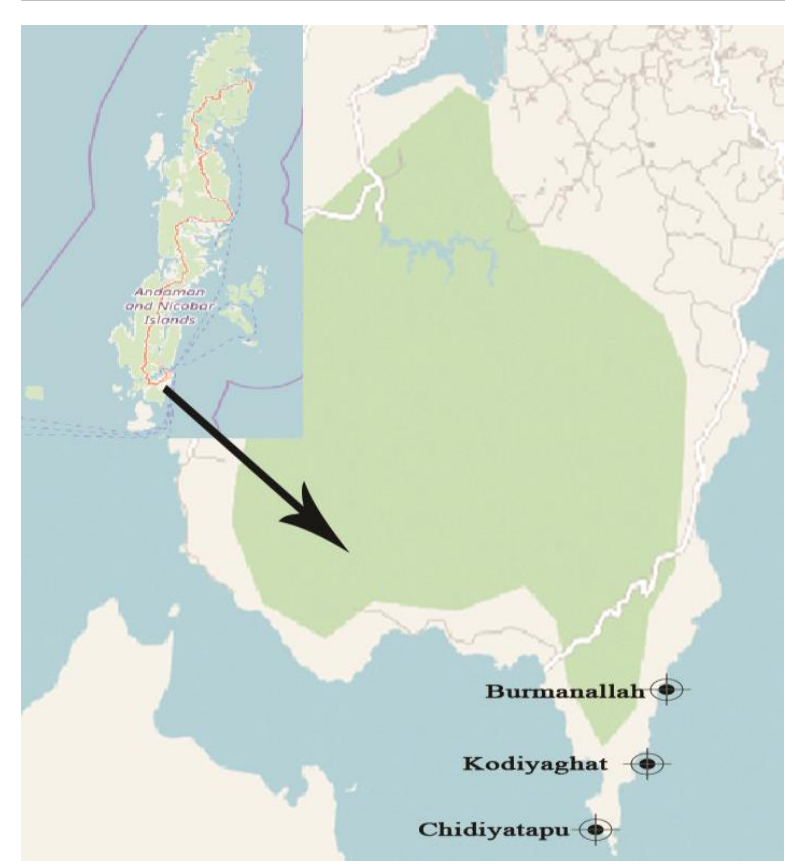

Figure 1. Map showing the three Study sites

ter of Andaman Island, especially from a typical tropical marine habitat of Indian EEZ leads to the present study.

\section{Material and Methods}

Three intertidal sites-Burmanallah (11³3’569 $\mathrm{N}$ and $\left.92^{\circ} 43^{\prime} 781 \mathrm{E}\right)$, Kodiyaghat $\left(11^{\circ} 31^{\prime} 473 \mathrm{~N}\right.$

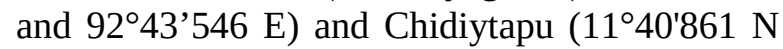
and $92^{\circ} 43^{\prime} 546 \mathrm{E}$ ) on the southeastern coasts of the Andaman Islands were investigated between June and August 2016 (Figure 1). Beginning up to an hour before low tide and continuing for up to an hour after low tide, the sample collection was done through the intertidal zone and covered up to 250 $\mathrm{m}$ parallel to the sea by snorkeling and handpicking. Boulders, smaller rocks, shells, and artificial materials close to the water's edge at low tide were overturned and examined.

Specimens thus obtained were air-dried and wrapped with paper for transport. The lengths of the colonies were measured using Vernier Calipers. In the laboratory, colonies on stones and rock fragments were removed and treated with Sodium hypoclorite sollution $(\mathrm{NaOCl})$ to remove the soft tissue and algal attachment. Then rinsed it in water, and air-dried. Some colonies became fragmented on the removal of specimens from large rocks. Then the specimens were examined by SMZ 1500 stereoscopic microscope. Bryozoan species was identified using standard identificati- on keys [1]. Environmental parameters from the study sites including temperature, salinity, $\mathrm{pH}$, dissolved oxygen were also estimated.

\section{Results and Discussion}

During the study period, the Maximum temperature of $30^{\circ} \mathrm{C}$ was recorded from Chidiyatapu in August. The monsoon rain might have resulted in the minimum temperature of $24^{\circ} \mathrm{C}$ in Burmanallah. Salinity varied from $26-32$ (psu) and the month of August contributed the maximum salinity recording from all the three stations. $\mathrm{pH}$ was altered from 7.6 - 7.9. Dissolved Oxygen was ranged from $3.5-4.2(\mathrm{mg} / \mathrm{L})$. In all the stations, DO level was almost maintained during of June and (Table 1).

A total of twelve genera were identified that included Smittipora sp., Hippopodina sp., Cupuladria sp., Hippaliosina sp., Membranipora sp., Schizoporella sp., Thalamoporella sp., Parasmittina sp., Caleschara sp., Antropora sp., Thalamoporella sp., and Tremogasterina sp. (Table 2). In the entire three stations, Thalamoporella sp. was the most abundant among the total collections. Smittipora sp., Hippaliosina sp., Membranipora sp., Schizoporella sp., Caleschara sp., Thalamoporella rozarii were got from two sites Burmanalla and Chidiyatapu. Antropora sp., Tremogasterina sp., Hippopodina sp. were reported only from Burmanallah, and Cupuladria sp. was reported only from Chidiyatapu. Burmanallah contributed the maximum number of species (nine) recorded from the study area followed by Chidiyatapu (eight), and Kodiyaghat was the least recorded area (three). The length of the colonial attachment on each substratum was also recorded using Vernier Calipers. The Thalamoporella sp. colony was the lengthiest colony $(3.5 \mathrm{~cm})$ with a broad spread of colonial growth throughout the rocks and giant clam shells. Whereas Parasmittina sp. and Cupuladria sp. were recorded with moderate length $(1.3 \mathrm{~cm}$ and $0.9 \mathrm{~cm}$ respectively). The lowest colony length was noticed for Hippopodina sp. and Hippaliosina sp. $(0.5 \mathrm{~cm})$ (Table 2).

In all the three stations the attachment on the rocks was most abundant. About $40 \%$ of the total colony collected was from the underneath of the rocks followed by the shell of Tridacna (Figure 2). Dead corals, bivalve shells were also provided substratum for the moderate attachment. No colo- 
Table 1. Environmental Parameters recorded during the study period for the three stations (BR - Burmanalla, KD - Kodiyaghat, CD - Chidiyatapu)

\begin{tabular}{|c|c|c|c|c|c|c|c|c|c|c|c|c|}
\hline & \multicolumn{6}{|c|}{ Temperature-Salinity $\left({ }^{\circ} \mathrm{C}\right)$} & \multicolumn{3}{|c|}{$\mathrm{pH}(\mathrm{psu})$} & \multicolumn{3}{|c|}{ Dissolved Oxygen $(\mathrm{mg} / \mathrm{L})$} \\
\hline & $\mathrm{BR}$ & $\mathrm{KD}$ & $\mathrm{CD}$ & $\mathrm{BR}$ & $\mathrm{KD}$ & $\mathrm{CD}$ & $\mathrm{BR}$ & $\mathrm{KD}$ & $\mathrm{CD}$ & $\mathrm{BR}$ & $\mathrm{KD}$ & CD \\
\hline June & 27 & 27 & 28 & 27 & 26 & 27 & 7.6 & 7.8 & 7.8 & 3.9 & 3.7 & 3.5 \\
\hline July & 24 & 26 & 25 & 29 & 29 & 30 & 7.9 & 7.7 & 7.7 & 3.8 & 3.6 & 3.7 \\
\hline August & 28 & 29 & 30 & 31 & 32 & 32 & 7.4 & 7.6 & 7.6 & 4 & 4.2 & 3.9 \\
\hline
\end{tabular}

Table 2. Bryozoan species list with Number of colonies, colony length range (minimum to maximum), mean length, Standard deviation $( \pm \mathrm{SD})$

\begin{tabular}{|c|c|c|c|c|c|c|c|c|c|c|c|c|}
\hline \multirow{2}{*}{ Bryozoan Species } & \multicolumn{4}{|c|}{ Burmanallah } & \multicolumn{4}{|c|}{ Kodiyaghat } & \multicolumn{4}{|c|}{ Chidiyatapu } \\
\hline & NoC & Range & ML & $\mathrm{SD}$ & NoC & Range & ML & $\mathrm{SD}$ & NoC & Range & ML & SD \\
\hline Smittipora sp. & 2 & $0.3-0.7$ & 0.5 & 0.2 & & & & & 1 & 0.4 & 0.4 & 0 \\
\hline Hippopodina sp. & 1 & 0.5 & 0.5 & 0 & & & & & & & & \\
\hline Cupuladria sp. & & & & & & & & & 1 & 0.9 & 0.9 & 0 \\
\hline Hippaliosina sp. & 1 & 0.5 & 0.5 & 0 & 2 & $0.4-0.5$ & 0.45 & 0.05 & & & & \\
\hline Membranipora sp. & & & & & 2 & $0.3-0.8$ & 0.55 & 0.25 & 1 & 0.5 & 0.5 & 0 \\
\hline Schizoporella sp. & 1 & 0.7 & 0.7 & 0 & & & & & & & & \\
\hline Thalamoporella sp. & 4 & $1.1-3.5$ & 2.3 & 0.89 & 2 & $0.7-2.5$ & 1.6 & 0.9 & 1 & 1.6 & 1.6 & 0 \\
\hline Parasmittina sp. & & & & & & & & & 1 & 1.3 & 1.3 & 0 \\
\hline Caleschara sp. & 1 & 0.6 & 0.6 & 0 & & & & & 2 & $0.4-0.6$ & 0.5 & 0.1 \\
\hline Antropora sp. & 1 & 0.5 & 0.5 & 0 & & & & & & & & \\
\hline T. rozierii & 3 & $1.5-2.1$ & 1.86 & 0.26 & & & & & 2 & $1.9-1.3$ & 1.6 & 0.3 \\
\hline Tremogasterina sp. & 1 & 0.7 & 0.7 & 0 & & & & & & & & \\
\hline
\end{tabular}

ny was recorded from the substratum of anthropogenic origins such as chappals, bottles, and fragments of constructions.

The suborder Anasca (order Cheilostomata) was by far the most significant component of the intertidal bryozoan fauna found in the study. The six genera were included under Anascan cheilostomes, and the remaining five belongs to Ascophoran cheilostomes. No species from the orders Ctenostomes and Cyclostomes were found in any of the three stations. All species were encrusting forms and no erect forms, either flexible or rigid, were found. In Chidiyatapu some of the colonies were found attached directly to the coral substratum. Moreover, many of these species were also found on calcareous shells upon the rock surface. The small colonies of Hippaliosina sp. and Cupuladria sp. were found encrusting on the shells of Lambis. Thalamoporella sp. were much more abundant on rocks, though colonies were also observed on other substrata. Chaleschara sp. was solely noticed in small cavities of rocks, Membrinopora sp. was found primarily encrusting on rocks and also, on some bivalve shells. The upper surfaces of rocks where bryozoans were encrusted and exposed to light were heavily coated with flexible macroalgae. Due to its thinness, not all colonies could be removed. In Chidiyatapu beach, several dead colonies of bryozoans were scraped out, of which few remained unidentified.

Among the three study sites, Burmanallah was the most diversified sites for the marine bryozoan species. The Chidiyatapu gave habitat for many coral reef-associated Bryozoan. The twelve species identified from three sites out of which four genera were reported during the previous studies $[6,7,8]$ and the remaining eight genera are a new record to this island. From all the three stations, the big rocks were the most preferred substratum for the bryozoans than entire calcareous platforms. This may be due to exceptional diversity and assemblage heterogeneity generally found in marine hard bottom habitats contribute significantly to species richness, abundance, and biomass [9]. In substratum rich environments, such as rocky shores, many Bryozoans display a high degree of 


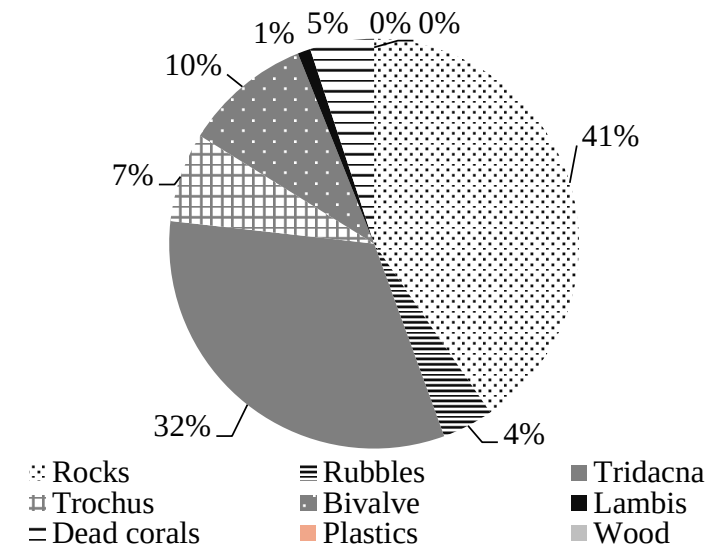

Figure 2. Showing the percentage of bryozoan attachment on the substratum

specificity in their habitat preferences. The dead shells of tridacna host most number of colony among the calcareous substrata. It should be due to the immense surface area of the giant clam shells for colonization compared to other mollusk shells [10]. There were very few attachments from small invertebrate shells, which may be due to its lack of sufficient attachment surface along with disturbance and replacement that could occur during the tidal activity [11]. Moreover, based on the study on epizoic bryozoan on cephalopod shells, Wyse Jackson and Key [12] analyzed that the rate at which these shells become available is very slow and directly dependent on the life cycle and abundance of the host organism, especially on their reproduction and mortality rates. In some rather inhospitable situations, Bryozoans appear to settle on whatever substrate is available [13]. However, no attachment was reported from the substratum with anthropogenic origin.

Bryozoans are one of the six group of invertebrates documented in a catalog of the central marine fouling organism [1]. Thalamoporella sp. which is one of the most biofouling species [14] reported is available in plenty throughout the three study sites. Two different species of genus Thalamoporella were reported in our study. The substratum selection mechanism of the Bryozoan is significant in ecological aspect since it is providing shelter for many invertebrate species, including other bryozoans [15] and thus they show their crucial role in the marine ecological balance. The intertidal bryozoans were also found to be food organisms for echinoids, starfish, brittle-stars, chitons, and opisthobranches [16]. A total of thirty species of coral associated bryozoans have recorded from the Indian coral reef, of which five species Tremogasterina sp., Parasmittina sp., Membranipora sp., Smittipora sp., and Thalamoporella sp. were reported in the present study. Our studies also revealed that the rocky platform is the most preferable substratum for the Bryozoans attachment in the intertidal waters of Andman Is land. A similar pattern of attachment abundance on the rocks is also reported from some temperate fjords [17].

The genera like Thalamoporella sp., Parasmittina sp., and Membranipora sp. reported from the Chidiyatapu were also included in a previously reported list from the Great Barrier Reef (GBR) and from Indo-Pacific reef [11]. However, many species, which belong to the common genera and are reported from other parts of the world such as, Stylopoma, Crassimarginatella, Micropora, Puellina, Hippothoa, Celloporaria, etc., have not been recorded from this Island territory of India.

\section{Conclusion}

Intertidal bryozoan fauna is a very diverse one, probably consisting of several species. However, Andaman bryozoan fauna of intertidal and coral reefs ecosystem is poorly understood. Our results suggested that the species of the most abundant bryozoans is that of Thalamoporella. Moreover, the majority of the genera recorded in the present study have a worldwide distribution along the shallow waters of the tropical and temperate seas. The most heavily colonized substrate was rocks, followed by the calcareous shells. This might be due to physical damages caused in the light shells owing to high wave actions and get easily turned over. A difference between epibiont species of tridacna shells and other dead shells were recorded. Tridacna shells seem to be more attractive and ease for the big colonies than small bivalves and mollusk shells. Our findings further emphasize the importance of rocky shores as a comfort station for the sessile invertebrates like bryozoan. To explore the diversity and ecological activities of bryozoans, a detailed study is most vital. Our results demonstrate that these Andaman Islands and surrounding regions deserve essential baseline surveys which are still lacking for even some of the better-studied taxa in the world, such as bryozoans. 


\section{Acknowledgment}

The authors are grateful to the Head of the Department of Marine Biology, Pondicherry University, Port Blair for providing all the necessary facilities. The authors feel especially grateful to Dr. Soja Louis and Srinivasu for help in identification. Dr. Dennis Gordon and (Late) Dr. N.R Menon are thanked for valuable comments.

\section{References}

1. Menon NR, Menon NNM (2006) Taxonomy of bryozoans from the Indian EEZ 1st Edition. Kochi, Ocean Science and Technology Cell.

2. Matthew HD, Andrei VG (2017) Rocky-intertidal cheilostome bryozoans from the vicinity of the Sesoko Biological Station, west-central Okinawa, Japan. Journal of Natural History 51 (3 -4): 141 - 266. doi: 10.1080/00222933.2016.1253797.

3. Pejin B, Mojović M, Savić AG (2013) Novel antitumour natural products from the phy-lum Bryozoa. Biologia Serbica 35 (1 2): $3-14$.

4. Bock PE, Gordon DP (2013) Phylum bryozoa Ehrenberg, 1831. In: Zhang, Z.-Q. (Ed.) Animal biodiversity: An outline of higher-level classification and survey of taxonomic richness (Addenda 2013). Zootaxa 3703 (1): 67 - 74. doi: 10.11646/zootaxa.3703.1.14.

5. Shrinivaasu S, Venkatraman C, Rajan R, Venkatraman K (2015) Marine bryozoans of India. In: Venkataraman K, Raghunathan C, Mondal T, Raghuraman R eds. Lesser known marine animals of India. India, Zoological Survey of India. pp 321 - 337.

6. Thornely LR (1905) Report on the Polyzoa. In: Herdman WA eds. Report to the Government of Ceylon on the pearl oyster fisheries of the Gulf of Mannar. London, The Royal Society. pp $107-115$.

7. Thornely LR (1907) Report on the marine Polyzoa in the collection of the Indian Museum. Records of Indian Museum 1: $179-196$.
8. Robertson A (1921) Report on a collection of Bryozoa from the Bay of Bengal and other eastern seas. Records of Indian $\mathrm{Mu}-$ seum 22: $33-65$.

9. Kostylev VE, Erlandsson J, Ming MY, Williams GA (2005) The relative importance of habitat complexity and surface area in assessing biodiversity: Fractal application on rocky shores. Ecological Complexity 2 (3): 272 - 286. doi: 10.1016/j.ecocom. 2005.04.002.

10. Vicentuan-Cabaitan K, Neo ML, Eckman W et al. (2014) Giant clam shells host a multitude of epibionts. Bulletin of Marine Science 90 (3): 795 - 796. doi: 10.5343/bms.2014.1010.

11. Ryland JS, Hayward PJ (1992) Bryozoa from Heron Island, Great Barrier Reef. Memoir of the Queensland Museum 32: 223 $-301$.

12. Jackson PNW, Key MMK Jr (2014) Epizoic bryozoans on cephalopods through the Phanerozoic: A review. Studi Trentini di Scienze Naturali 94 (2014): 283 - 291.

13. Soja L (2007) Taxonomy, bionomic, and biofouling of bryozoans from the coasts of India and the Antarctic Waters. Ph.D. Thesis. Cochin University of Science and Technology. Marine Biology Department.

14. Seo JE, Min BS (2009) A faunistic study on Cheilostomatous bryozoans from the Shoreline of South Korea, with two new species. Korean Journal of Systematic Zoology 25 (1): 19 - 40. doi: 10.5635/KJSZ.2009.25.1.019.

15. Sharp JH, Winson MK, Wade S et al. (2008) Differential microbial fouling on the marine bryozoan Pentapora fascialis. Journal of Marine Biological Association of United Kingdom 88 (4): 705-710. doi: 10.1017/S0025315408001215.

16. Lidgard S (2008) Predation on marine bryozoan colonies: Taxa, traits, and trophic groups. Marine Ecology Progress Series 359: 117 - 131. doi: 10.3354/meps07322.

17. Kuklinski PA, Sokolowski A, Ziolkowska M et al. (2010) Growth rate of selected sheet-encrusting bryozoan colonies along a latitudinal transect - preliminary results. In: Ernst A, Schäfer P, Scholz J eds. Bryozoan Studies 2010. Berlin, Springer Verlag. pp 155 - 167. doi: 10.1007/978-3-642-164118_11. 